FACTA UNIVERSITATIS

Series: Teaching, Learning and Teacher Education Vol. 3, No 2, 2019, pp. 83 - 93

https://doi.org/10.22190/FUTLTE1902083R

Original research paper

\title{
CONNECTION BETWEEN CLASSROOM CLIMATE AND ACADEMIC PERFORMANCE
}

\author{
UDC $37.064: 371.26 ; 37.015 .3$
}

\section{Dušan Ranđelović, Danica Dimić}

University of Priština temporarily settled in Kosovska Mitrovica, Faculty of Philosophy, Department of Psychology, Kosovska Mitrovica, Serbia

\begin{abstract}
The goal of this study was to examine the relationship between academic performance and certain dimensions (components) of classroom climate (teacherstudent interaction, social climate, fear of failure, and emotional climate), as well as the relationship between classroom climate components and sociodemographic variables. The sample included 180 sixth and eighth grade students from elementary schools in Leskovac. For the purposes of this study we used the Presence scale of classroom climate components and the General questionnaire created for this research. The results indicate that there is no statistically significant correlation between the classroom climate components and academic performance. Boys had higher scores when it came to the "social climate" component, while "fear of failure" was more expressed among girls. Younger students had higher scores with regard to the "teacher-student interaction" component and "emotional climate" component than the older ones. These results are partly in line with some previous studies and emphasize that it is very important to take into account the classroom climate that students are learning in, which may indirectly affect students' academic performance.
\end{abstract}

Key words: classroom climate, academic performance, classroom interaction, students, elementary school

\section{INTRODUCTION}

Research into the classroom climate and school climate began in the late 1950s, most frequently based on research into school staff perceptions of the school organization, as well as into the factors that affect school efficiency.

Received September 18, 2019/Accepted November 28, 2019

Corresponding author: Dušan Ranđelović

Faculty of Philosophy, University of Priština temporarly settled in Kosovska Mitrovica, Filipa Višnjića bb,

38220 Kosovska Mitrovica, Serbia

Phone: +38128425 473•E-mail: dusan.randjelovic@pr.ac.rs

(C) 2019 by University of Niš, Serbia | Creative Commons License: CC BY-NC-ND 
Classroom climate can be warm, friendly and cordial in one class, moderate and cooperative in another class, and cold and hostile in a third one. Productive classroom environment is a type of social relationship in the classroom and a form of communication between teachers and students and their emotional connections that lead to good and lasting learning outcomes and an optimum classroom climate.

In a positive classroom environment, that, is in a relaxed, understanding and tolerant environment, children ask questions and seek answers about everything that interests them, leading to creativity and cognition, as well as to developing critical and creative thinking.

Studies show the following characteristics of a favorable social and emotional climate in the classroom: a relaxed and spontaneous climate, respect for each student's individual abilities and personality traits, classroom activities where students can satisfy their learning interests and curiosity, a favorable emotional climate and motivation to learn, open communication between students, collaboration, co-operation and group work, connecting lessons with real life examples, etc. (Stojaković, 2012).

V. Andrilović and M. Čudina (1985) mention four components of classroom climate:

- teacher-student interaction

- social climate

- competitive and collaborative environment

- emotional climate (According to: Stojaković, 2002, p. 153).

Studies on teacher-student interaction have shown that the type and quality of classroom interaction affects learning outcomes (Huitt, 2003). Good student-teacher relationship also has a positive impact on students' social functioning (Ladd, Birch, \& Buhs, 1999), while it preventively affects student discipline and behavior problems (Graziano et al., 2007). Hughes et al. argue that increased teacher support can help aggressive and rejected children to be accepted by their peers.

Several studies have found a significant correlation between the quality of student relationship with the teacher and variables important for academic performance such as: participation in learning activities (Skinner, Wellborn, \& Connell., 1990), positive attitude towards school (Gest, Welsh, and Domitrovich, 2005) and higher order thinking and performance skills (Gest, Welsh, and Domitrovich, 2005; Valiente, Lemery-Chalfant, Swanson, \& Reiser, 2008; Wentzel \& Wigfield, 1998). Research findings indicate that student relationship with teacher can predict not only his/her academic success but also peer acceptance (Howes, Matheson, \& Hamilton, 1994; Hughes, \& Cavell, 1999).

The studies show that there is a direct correlation between a teacher who encourages student participation in learning activities and positive attitude towards school, learning and the classroom (Flanders, 1970). Students whose teachers show an interest in their emotional problems and needs have better social relationship with their peers, exhibit less asocial behavior and are less absent from school (Withall, 1964).

Classroom social climate is also important for student academic performance (Đorđević, 1989). Classroom social climate depends on the conditions under which a student group is formed, the level of agreement upon common goals, the way the group is managed, the position of an individual member in the group, their mutual relationship, the readiness of the group members to collaborate during learning activities and work together to achieve the goals set, etc. Classroom social climate can be a significant factor in whether a class will function properly, it can affect interpersonal relationships, and the level of satisfaction or dissatisfaction with the learning methods and learning objectives. Peer-to-peer interaction allows for the development of social skills, social competence, and emotional stability. 
Being close to peers develops a sense of responsibility, solidarity, interpersonal sensitivity, trusting other people, but also develops self-esteem and self-confidence. Developed prosocial skills are an important prerequisite for building positive social relationships, but they also affect the school adjustment and academic achievement. Collaborative and supportive behavior establishes a positive, academically relevant interaction between a student and his/her teacher and peers, which is a desired environment for the successful learning and teaching process (Spasenović, 2004).

Student self-initiative activities, collaborative activities, student self-assessment and critical activities in terms of criticism or praise of others' work, but along with selfevaluation and self-criticism, as well as the organizational, leadership and learning activities provide information and give an insight into the social and emotional climate in the classroom. Most studies have shown that the best learning outcomes are achieved by those teaching methods where on the one hand there is teacher control and activity, and on the other hand student activity (Stojaković, 2012).

Peer acceptance and sense of security are an important basis for the development and advancement of each individual and they provide for the fostering of cognitive development and student academic success (Spasenović, 2008).

Student academic performance is also affected by their choice of friends, that is, the characteristics, attitudes and behaviors of the peers they are friends with. The behavior of their peers, especially friends, their friends' academic performance and attitudes regarding the need to have good academic performance are significant factors that can affect student performance (Veronneau, \& Dishion, 2011).

Emotional climate significantly affects student emotional safety, satisfaction and mental health as well as their learning outcomes. Emotional climate depends on the type of teacherstudent interaction, the level of democracy in the classroom, on student motivation, on the emotional stability of students and teachers, etc. (Stojaković, 2012).

Studies show that if the prevailing classroom climate is that of fear and distrust, especially if the fear of failure is constantly present, it can have a very unfavorable impact on student potentials. In a climate of fear and misunderstanding, not only does the quality of emotional relationships deteriorate, but it can also lead to severe personality disorders, that is, to a climate of fear of failure that prevents normal behavior and regular school attendance. Fear of failure is the most common cause of bad behavior in school. Student self-image and self-confidence significantly affect his/her academic performance (Stojaković, 2012).

Academic performance is considered to be the result of the overall student learning activities and influences, not just the progress made regarding the knowledge acquired (Gojkov, 1997). It is affected by a number of factors that interact with each other. If students feel that they have control over their own learning outcomes, it increases their self-confidence and self-affirmation. The experience of success or failure significantly affects child's assessment of his or her own abilities and anticipation of success in the future. Experiencing success or failure involves not only reacting subjectively to academic performance, but also the impact of feedback of students' family, teacher, or peers regarding students' academic achievement (Brković, 1994).

Continual fear of failure causes general insecurity and fear, and constant or often experienced failure diminishes interest, leads to frustration and resistance to further learning, causes students to lose confidence in their own abilities, weakens their confidence, decreases motivation for active participation in learning activities, which causes a child to withdraw into him or herself and leads to recurring failures (Bilić, 2001; Krnjajić, 2002). 
Student behavior in school has an impact on the quality of classroom climate. Positive and supportive school and classroom climate produces student academic success (Marshall, 2004).

The correlation between classroom climate and student academic performance is also confirmed by data from several studies that have shown that students with better academic performance claimed that their classroom climate was positive, which was not the case with students with poorer academic performance (Pritchard, Morrow \& Marshall, 2005).

\section{RESEARCH METHOD}

\subsection{Problem, goals and objectives}

The subject of this research is to examine the connection between classroom climate and academic performance of sixth and eighth grade students.

The overall objective of this research is to examine whether there is a correlation between the main components of classroom climate and academic performance of sixth and eighth grade students. The main components of classroom climate are: teacherstudent interaction, social climate, emotional climate and fear of failure.

Research objectives:

- Identify how present the main components of classroom climate are in students (teacher-student interaction, social climate, emotional climate and fear of failure).

- Investigate whether there was a correlation between the main components of classroom climate and student academic performance in the previous school year.

- Identify the difference in the level of main components of classroom climate in relation to student gender.

- Investigate whether there is a difference in the level of main components of classroom climate in relation to student grade.

- Investigate whether there is a correlation between socioeconomic status and the main components of classroom climate.

\subsection{Variables and instruments}

Classroom climate - which includes four components (teacher-student interaction, social climate, emotional climate and fear of failure). Classroom climate data were obtained from a questionnaire created for the purposes of this research. Teacher-student interaction refers to the quality of communication between students and teachers, mutual understanding and trust, teacher's readiness to respect students' needs, etc. High scores indicate successful communication, high levels of trust and mutual respect. Social climate refers to peer-to-peer interaction in the classroom, peer acceptance, level of agreement regarding common goals, the position of an individual member in the group, the willingness of the group members to collaborate, etc. Fear of failure is a student subjective experience of a lesson, which is characterized by unpleasant feelings, anxiety, and shame, and is mainly linked to test anxiety. The total score for these components is obtained by simply summarizing the items. Emotional climate refers to the subjective emotional experience in the classroom and in lessons.

The presence scale of classroom climate components was created for the purposes of this research and consists of four subscales. The first three scales are part of the 
instrument designed for this research. The scale is the Likert-type scale; namely, the students were asked to use the scale from 1 to 5 to rate the degree to which they agree or disagree with each statement, where 1 would mean "I completely disagree", 2 would mean "I partially disagree", 3 would be "I am uncertain", 4 - "I partially agree", and 5 "I completely agree".

The first subscale consists of 15 statements regarding teacher-student interaction. ("Our teacher treats all students fairly"). The second subscale examines the social climate in the classroom and contains 11 statements. ("Some students constantly argue in our class"). The third subscale consists of 9 statements and refers to the fear of failure. ("I often feel bad before a test"). The initial version of the instrument contained 45 items. After conducting the pilot survey and verification, 35 items were retained. The factor analysis of the final form of the instrument confirmed the existence of 3 interpretable factors. The fourth subscale was subsequently added to the already constructed instrument; it is in the form of semantic differential and it refers to the classroom emotional climate. This part of the scale was borrowed from the author Ranđelović (Ranđelović, 2009). Students were asked to look at this scale and pick and circle a number from -3 to 3 [3]; the scale included three pairs of adjectives which described subjective emotional experience in the classroom. In order to verify the reliability of the instrument created for the purposes of this research, a pilot study was conducted in November in a seventh grade class. The following results were obtained for each classroom climate component and they are expressed as Cronbach's alpha coefficient: Teacher-student interaction: 0,711 ; social climate: 0,703 ; emotional climate: 0,728 . As for the "fear of failure" component, we borrowed the statements from the research "Classroom climate and student satisfaction with learning" (Jagić and Jurčić, 2006.)

Student academic performance - expressed by students' overall performance in the previous school year, and their performance in the selected subjects: Serbian language, mathematics and second language. Academic performance data were obtained through a general questionnaire where students wrote down grades in the selected subjects, as well as their overall performance at the end of the previous school year.

\subsubsection{Socio-demographic variables}

Student gender - two-level categorical variable: 1-male, 2-female;

Age - numerical variable;

School grade - two-level categorical variable: 1-sixth, 2-eighth;

Place of residence - big city, small town, village, private property;

Student family's financial situation - This variable was considered numerical during the analysis, where the lower value represented worse financial situation and the higher value represented better financial status. These sociodemographic variables were collected using a general questionnaire created for the purposes of this research. It contains questions that were used to collect data regarding gender, age, place of residence, financial situation as well as student academic performance in the previous school year as well as the grades in mathematics, Serbian and second language.

\subsection{Sample and procedure}

The sample included 180 sixth and eighth grade elementary school students. The research was conducted at the elementary school "Svetozar Markovic" and the elementary school "Kosta Stamenkovic" in Leskovac, in the 2016/2017. school year. The study 
included two sixth-grade and two eighth-grade classes from two city schools. The sample size is appropriate, but certain sample characteristics were taken into account when deciding upon the sample: a) approximately equal numbers of males and females; b) schools from the inner-city area attended by students from suburban areas and rural areas.

The survey was conducted in January 2017 in Leskovac. It included two sixth-grade and two eighth-grade classes from two city elementary schools - "Svetozar Marković" and "Kosta Stamenković". The study involved 180 students, 99 of which were boys (55\%) and 81 of which were girls (45\%), 138 students living in the city, and 42 in the villages, 97 students $(53.9 \%)$ attending sixth grade and $83(46.1 \%)$ attending eighth grade. The study was carried out during the second and third lesson, and the procedure and purpose of the study were briefly explained to the students. The survey was anonymous with the approval of the principal and the teacher who was teaching the class at the time. It took an average of 15 minutes to complete the questionnaire.

\subsection{Statistical Data Analysis}

In order to analyze the data in this study, we used descriptive statistics (arithmetic mean, standard deviation, frequency and percentages) as well as statistical tools to calculate the correlation between certain variables and difference between them (Pearson correlation coefficient, independent-samples $t$-test).

\section{RESULTS}

In presenting the results of the research, we decided to start with some basic descriptive parameters expressing the level of certain aspects of classroom climate in the respondents. These results are shown in Table 1.

Table 1 The level of main components of classroom climate (Descriptive Statistics)

\begin{tabular}{lccccc}
\hline & $\mathrm{N}$ & Min & Max & M & SD \\
\hline Teacher-student interaction & 180 & 1 & 5 & 3.47 & 4.848 \\
Social climate & 180 & 1 & 5 & 2.77 & 5.716 \\
Fear of failure & 180 & 1 & 5 & 2.99 & 4.867 \\
Emotional climate & 180 & 1 & 7 & 5.51 & 1.420 \\
\hline
\end{tabular}

Pearson correlation coefficient was used to examine the connection between individual components of classroom climate and academic performance. The results are shown in Table 2.

Table 2 The connection between the main components of classroom climate and academic performance

\begin{tabular}{llcccc}
\hline & Emotional climate & $\begin{array}{c}\text { Teacher-student } \\
\text { interaction }\end{array}$ & Social climate & $\begin{array}{c}\text { Fear of } \\
\text { failure }\end{array}$ \\
\hline Academic & $\mathrm{r}$ & .043 & .093 & -.037 & .052 \\
Performance & Sig & .563 & .215 & .626 & .484 \\
& $\mathrm{~N}$ & 180 & 180 & 180 & 180 \\
\hline
\end{tabular}


The results shown in Table 2 show that there is no statistically significant correlation between the main components of classroom climate (emotional climate, teacher-student interaction, social climate, fear of failure) and academic performance.

The difference in the level of main components of classroom climate in relation to student gender was verified by using the independent-samples t-test, and the results are shown in Table 3.

Table 3 The difference in the level of main components of classroom climate in relation to gender

\begin{tabular}{|c|c|c|c|c|c|c|c|}
\hline Classroom climate components & Gender & $\mathrm{N}$ & AS & SD & $\mathrm{t}$ & $\mathrm{df}$ & Sig \\
\hline \multirow[t]{2}{*}{ Emotional climate } & Male & 99 & 5.4074 & 1.595 & \multirow{2}{*}{-1.103} & \multirow{2}{*}{178} & \multirow{2}{*}{.271} \\
\hline & Female & 81 & 5.6420 & 1.167 & & & \\
\hline \multirow[t]{2}{*}{ Teacher-student interaction } & Male & 99 & 51.88 & 5.037 & \multirow{2}{*}{-1.137} & \multirow{2}{*}{178} & \multirow{2}{*}{.257} \\
\hline & Female & 81 & 52.70 & 4.597 & & & \\
\hline \multirow[t]{2}{*}{ Social climate } & Male & 99 & 31.27 & 5.843 & \multirow{2}{*}{2.112} & \multirow{2}{*}{178} & \multirow{2}{*}{.036} \\
\hline & Female & 81 & 29.48 & 5.432 & & & \\
\hline \multirow[t]{2}{*}{ Fear of failure } & Male & 99 & 26.16 & 4.911 & \multirow{2}{*}{-2.400} & \multirow{2}{*}{178} & \multirow{2}{*}{.017} \\
\hline & Female & 81 & 27.89 & 4.669 & & & \\
\hline
\end{tabular}

Table 3 shows that there are no significant differences in the level of emotional climate component and teacher-student interaction when comparing male and female respondents.

The independent-samples $t$-test (Table 3 ) compared the results of boys' and girls' attitudes about social classroom climate. There was a statistically significant difference $(\mathrm{t}=$ $2.112, \mathrm{df}=178, \mathrm{p}<0.05)$ between the mean values of the dependent variable in each of the two groups (boys: $\mathrm{M}=31.27, \mathrm{SD}=5.84$; girls: $\mathrm{M}=29.48 \mathrm{SD}=5.43$ ). Eta-squared was 0.02, which means that gender differences explain 2 percent variance for the social climate in the classroom.

Difference in the levels of fear of failure in male and female respondents was also confirmed $(\mathrm{t}=-2.40, \mathrm{df}=178, \mathrm{p}<0.05)$. Eta-squared $=0.03$ which would mean that there is moderate effect of this component. Fear of failure is more pronounced in girls and the mean is 27.89 while standard deviation is 4.66 . In boys, the mean was 26.16 and $\mathrm{SD}=4.91$.

The difference in the level of main components of classroom climate in relation to students' grade was verified as well, and the results are shown in Table 4.

Table 4 The difference in the level of main components of classroom climate in relation to grade

\begin{tabular}{llcccccc}
\hline Classroom climate components & Grade & N & AS & SD & t & df & Sig \\
\hline Emotional climate & Sixth & 97 & 17.64 & 3.562 & 3.812 & 178 & .002 \\
& Eighth & 83 & 15.25 & 4.653 & & & \\
Teacher-student interaction & Sixth & 97 & 52.99 & 5.522 & 2.302 & 178 & .004 \\
& Eighth & 83 & 51.39 & 3.770 & & & \\
Social climate & Sixth & 97 & 29.89 & 5.425 & -1.477 & 178 & .373 \\
& Eighth & 83 & 31.14 & 6.000 & & & \\
Fear of failure & Sixth & 97 & 27.40 & 4.896 & 1.384 & 178 & .901 \\
& Eighth & 83 & 26.40 & 4.806 & & & \\
\hline
\end{tabular}


There was a statistically significant difference (Table 4) regarding the teacher-student interaction component between sixth and eighth grade students $(t=2.302$, df $=178, \mathrm{p}$ $<0.05)$. For sixth grade students: $M=52.99 \mathrm{SD}=5.52$ while for eighth grade students $\mathrm{M}=51.39 \mathrm{SD}=3.77$. Eta-squared was 0.01 , which means that student grade difference explains $1 \%$ variance for the teacher-student interaction.

The independent samples $t$-test compared the results of emotional climate in the sixth and eighth grade students. It was found that there was a statistically significant difference $(t=3.812, \mathrm{df}=178, \mathrm{p}<0.05)$ in sixth grade students $(\mathrm{M}=17.64, \mathrm{SD}=3.56)$ and eighth grade students $(\mathrm{M}=15.25 \mathrm{SD}=4.65)$. The difference between the mean values (mean difference $=2.3895 \% \mathrm{Cl}: 1.12$ to 3.62 ) is significant and has a moderate influence (etasquared $=0.07$ ) which would mean that student grade difference explains $7 \%$ variance for emotional climate component.

Regarding the social climate and fear of failure component, no statistically significant differences were found between male and female respondents in the level of the above mentioned classroom climate components.

Table 5 Correlation between the socioeconomic status and the main components of classroom climate

\begin{tabular}{llccc}
\hline & Classroom climate & $\begin{array}{c}\text { Number of } \\
\text { components }\end{array}$ & $\begin{array}{c}\text { Correlation } \\
\text { coefficient }\end{array}$ & Significance \\
\hline \multirow{3}{*}{ Socioeconomic } \\
status & Teacher-student interaction & 180 & 0.079 & 0.294 \\
& Social climate & 180 & 0.115 & 0.124 \\
& Fear of failure & 180 & 0.077 & 0.303 \\
& Emotional climate & 180 & $0.166^{*}$ & 0.026 \\
\hline
\end{tabular}

The results presented in Table 5 show that there is a significant positive correlation between socioeconomic status and the emotional climate component, which would mean that students with higher socioeconomic status gave higher scores to the emotional climate component. The correlation is significant at the 0.05 level.

\section{DISCUSSION}

The quality of life and work in school depends on the quality of classroom climate, which is closely linked with the behavior of all participants in the education process. Achieving learning objectives depends on a number of factors. The term classroom climate refers to the correlation between the factors that affect the achievement of learning objectives. This term denotes the relatively lasting quality of the relationships between the main participants in the learning process, which is usually affected by a certain emotional climate. These main participants in the learning process - teachers and students - are certainly the ones who determine the quality of the overall classroom climate. Studies on teacher-student interaction have shown that the type and quality of classroom interaction significantly affects learning outcomes (Huitt, 2003 [K1]) Classroom social climate can be a significant factor in whether a class will function properly, it can affect interpersonal relationships, and the level of satisfaction or dissatisfaction with the learning methods and learning objectives. The emotional climate significantly affects the emotional safety, satisfaction and mental health of the students as well as their learning outcomes. 
Fear of failure is the most common cause of bad behavior in school. Students' self-image and self-confidence significantly influence his/her academic performance (Stojaković, 2012).

The goal of this study was to examine whether there was a correlation between academic performance and the main components of classroom climate (teacher-student interaction, social climate, fear of failure, and emotional climate. This study did not find a statistically significant correlation between the main components of classroom climate and academic performance of sixth and eighth grade students. The results indicate that there is a significant positive correlation between the socioeconomic status and the emotional climate component, which would mean that students with higher socioeconomic status gave higher scores to the emotional climate component. Boys are better at evaluating social climate, while fear of failure is more pronounced in girls.

Sixth-grade students showed a higher level of teacher-student interaction component and emotional climate component, thus indirectly confirming the results of some earlier studies that the perception of school climate is becoming increasingly negative year after year (Way, Reddy, Rhodes, 2007 [K2]).

The results of previous studies in this field indicate that classroom climate is linked to a number of phenomena such as violence, sense of security, academic performance, delinquency, satisfaction with learning, etc. Improving the classroom climate requires analysis, assessment, and continuous monitoring, which further means that classroom climate has to be observed as a multidimensional phenomenon, which would include teacher-student interaction, social climate, emotional climate, and fear of failure. The goal should be to create an instrument to assess classroom climate that fits our education system.

Continuous monitoring of classroom climate, including the school climate in general, its measurement, analysis, assessment and constant monitoring, could improve and benefit various aspects of students' lives, including their academic performance, behavior during and after class, as well as student satisfaction with learning and teaching.

\section{CONCLUSION}

Classroom climate is undeniably an important aspect of the learning process. We have already mentioned that there is a small number of empirical studies which have studied this topic. Our paper is an attempt to investigate and measure different components of classroom climate and to relate those components to the overall academic performance. Although we initially expected for academic performance to be significantly correlated to the classroom climate, the data did not confirm such assumptions. Of course, one must also take into account the limitations and shortcomings of the research, primarily with regard to the study sample that was not random, as well as the application of a new instrument used to measure the components of classroom climate, which should undergo additional psychometric checks. We consider the results obtained in our research to be a modest contribution to the study of the broader and more complex classroom climate topic, and we hope that the researchers will be inspired to focus their empirical efforts on this topic.

Acknowledgement: The work is a part of research activities on the project Kosovo and Metohija between National Identity and Eurointegration (no. 47023) funded by the Ministry of Education, Science and Technological Development of the Republic of Serbia. 


\section{REFERENCES}

Andrilovic, V., \& Cudina, M. (1985). Psihologija učenja i nastave. Zagreb: Školska knjiga.

Bilić, V. (2001). Uzroci, posljedice i prevladavanje školskog neuspjeha. Zagreb: Hrvatski pedagoško-književni zbor.

Brković, A. (1994). Uticaj uspeha i neuspeha na ličnost učenika. Užice: Učiteljski fakultet.

Đigić, G. (2013). Ličnost nastavnika i stilovi upravljanja razredom (Doktorska disertacija), Univerzitet u Nišu: Filozofski fakultet.

Đorđević, J. (1989). Teškoće u učenju i problemi neuspeha u nastavi. Nastava i vaspitanje, 4, 291-302.

Đorđić, D., i Damjanović, R. (2016). Školska klima, njen značaj za ponašanje učenika i mogućnosti merenja, Teme: Časopis za društvene nauke, 40(1), 301-317.

Flanders, N. A. (1970). Analyzing teacher behavior (pp. 100-107). Addison-Wesley P. C.

Gest, S. D., Welsh, J. A., \& Domitrovich, C. E. (2005). Behavioral predictors of changes in social relatedness and liking school in elementary school. Journal of school psychology, 43(4), 281-301.

Glasser, W. (1994). Kvalitetna škola. Zagreb: Educa.

Gojkov, G. (1997). Dokimologija: Priručnik. Beograd: Učiteljski fakkultet, Vršac: Viša škola za obrazovanje vaspitača.

Graziano, P. A., Reavis, R. D., Keane, S. P., \& Calkins, S. D. (2007). The role of emotion regulation in children's early academic success. Journal of school psychology, 45(1), 3-19.

Howes, C., Matheson, C. C., \& Hamilton, C. E. (1994). Maternal, teacher, and child care history correlates of children's relationships with peers. Child development, 65(1), 264-273.

Hughes, J. N., \& Cavell, T. A. (1999). Influence of the teacher-student relationship in childhood conduct problems: A prospective study. Journal of clinical child psychology, 28(2), 173-184.

Huitt, W. (2003). A transactional framework of the teaching/learning process. Educational psychology interactive. Valdosta, GA: Valdosta State University.

Jagić, S., i Jurčić, M (2006) Razredno-nastavno ozračje i zadovoljstvo učenika nastavom. Acta Iadertina, 3, 29-43.

Jurčić, M. (2006). Učenikovo opterećenje nastavom i razredno-nastavno ozračje. Odgojne znanosti, 8(2(12)), 329-346.

Krnjajić, S. (2002). Socijalni odnosi i obrazovanje. Beograd: Intitut za pedagoška istraživanja.

Ladd, G. W., Birch, S. H., \& Buhs, E. S. (1999). Children's social and scholastic lives in kindergarten: Related spheres of influence?. Child development, $70(6), 1373-1400$.

Marshall, M. L. (2004). Examining school climate: defining factors and educational influences [white paper, electronic version]. Retrieved from http://education.gsu.edu/schoolsafety/

Pritchard, R. J., Morrow, D., \& Marshall, J. C. (2005). School and district culture as reflected in student voices and student achievement. School Effectiveness and School Improvement, 16(2), 153-177.

Ranđelović, D. (2017). Efikasnost i psihološke onove nastave putem rešavanja problema uviđanjem. Kosovska Mitrovica: Filozofski fakultet.

Skinner, E. A., Wellborn, J. G., \& Connell, J. P. (1990). What it takes to do well in school and whether I've got it: A process model of perceived control and children's engagement and achievement in school. Journal of educational psychology, 82(1), 22.

Spasenović, V. (2004). Prosocijalnso ponašanje i školsko postignuće učenika. Zbornik radova instituta za pedagoška istraživanja, Beograd, br. 36, 131-148.

Stojaković, P. (2010). Pedagoška psihologija II, Banja Luka: Filozofski fakultet.

Stojaković, P. (2012). Psihologija za nastavnike, Banja Luka: Grafid.

Valiente, C., Lemery-Chalfant, K., Swanson, J., \& Reiser, M. (2008). Prediction of children's academic competence from their effortful control, relationships, and classroom participation. Journal of educational psychology, 100(1), 67.

Véronneau, M. H., \& Dishion, T. J. (2011). Middle school friendships and academic achievement in early adolescence: A longitudinal analysis. The Journal of early adolescence, 31(1), 99-124.

Way, N., Reddy, R., \& Rhodes, J. (2007). Students' perceptions of school climate during the middle school years: Associations with trajectories of psychological and behavioral adjustment. American journal of community psychology, 40(3-4), 194-213.

Wentzel, K. R., \& Wigfield, A. (1998). Academic and social motivational influences on students' academic performance. Educational Psychology Review, 10(2), 155-175.

Withall, J. (1964). Mental health in the classroom. Journal of Teacher Education, 15(2), 193-199.

Hiebert, J. \& Wearne, D. (1993). Instructional tasks, classroom discourse, and student learning in second grade. Americian Educational Research Journal, (30), 393-425.

Zdravković, D., Savić, Z. \& Šiljak, V. (2014). The "Sokol" movement as a model of intercultural cooperation. Historicky Casopis, 62(4), 679-693. 
Cummings, E., Schermerhorn, A., Merrilees, C., Goeke-Morey, M., Shirlow, P., \& Cairns, E. (2010). Political violence and child adjustment in Northern Ireland: Testing pathways in a social-ecological model including single-and two-parent families. Developmental Psychology, 46, 827-841. Doi: 10.1037/a0019668.

Milojević, M. and Zlatković, B. (2012). Motivacija postignuća - razvoj i savremena teorijska određenja [Achievement Motivation - Development and Contemporary Theoretical Determinations]. Godišnjak Učiteljskog fakulteta u Vranju [Annual of Teacher Training Faculty in Vranje], 3, 207-222.

\section{POVEZANOST RAZREDNE ATMOSFERE I ŠKOLSKOG USPEHA}

Cilj ovog istraživanja bio je ispitati vezu između školskog uspeha i pojedinih dimenzija (komponenti) razredne atmosfere (interakcija nastavnik-učenik, socijalna atmosfera, osećaj straha od neuspeha $i$ emocionalna atmosfera), kao $i$ vezu između dimenzija razredne atmosfere $i$ sociodemografskih varijabli. Uzorak je činilo 180 učenika šestog i osmog razredna osnovnih škola

u Leskovcu. U istraživanju su korišćeni skala izraženosti dimenzija razredne atmosfere i upitnik opštih podataka sastavljeni za potrebe ovog istraživanja. Rezultati pokazuju da ne postoji statistički značajna povezanost između dimenzija razredne atmosfere i školskog uspeha. Dečaci su imali više skorove kada je reč o dimenziji "socijalna atmosfera", dok je "strah od neuspeha" bio izraženiji kod devojčica. Mlađi učenici imali su veću izraženost dimenzije "interakcija nastavnik-učenik" $i$ "emocionalna atmosfera" u odnosu na starije. Ovakvi rezultati delimično se poklapaju sa ranijim istraživanjima i naglašavaju važnost vođenja računa o razrednoj atmosferi u kojoj se nastava odvija, što indirektno može delovati na školsko postignuće učenika.

Ključne reči: razredna atmosfera, školski uspeh, razredna interakcija, učenici, osnovna škola 